\title{
Karaciğer fibrozisli olgularda serum iskemi modifiye albüminin değerlendirilmesi
}

\author{
Assessment of serum ischemia modified albumin in cases with liver fibrosis
}

\author{
(D) Mustafa TAHTACI ${ }^{1}$, (D Murat BAŞARAN ${ }^{1}$, (D Hüseyin KÖSEOĞLU1', (D Fatma YILDIRIM²,

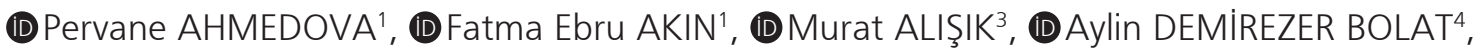 \\ (D) Fatih KIVRAKOĞLU', (D) Özcan EREL ${ }^{3}$, (DOsman ERSOY'
}

Ankara Yıldırım Beyazıt Üniversitesi Tıp Fakültesi, ${ }^{1}$ Iç Hastalıkları Anabilim Dalı, ${ }^{3}$ Biyokimya Anabilim Dalı, Ankara

Ankara Atatürk Eğitim ve Araştırma Hastanesi, ${ }^{2}$ Patoloji Laboratuvarı, ${ }^{4}$ Gastroenteroloji Kliniği, Ankara

Giriş ve Amaç: Serum iskemi modifiye albümin, iskemi ve oksidatif stresi göstermede kullanılan faydalı bir belirteçtir. Bu çalışmada serum iskemi modifiye albümin ve iskemi modifiye albümin tabanlı modellerin karaciğer fibrozisini öngörmede rolünün değerlendirilmesi amaçlandı. Gereç ve Yöntem: Çalışmaya 2013-2016 tarihleri arasında kronik karaciğer hastalığı ön tanısıyla karaciğer biyopsisi yapılan hastalar dahil edildi. Hastaların biyopsileri tek bir patolog tarafından değerlendirildi. Fibrozis derecelerine göre hastalar sınıflandırıldı. Tüm olguların hemogram parametreleri, kreatinin, aspartat aminotransferaz, alanin aminotransferaz, total bilirübin, direk bilirübin, albümin, iskemi modifiye albümin ve iskemi modifiye albümin/albümin oranı düzeyleri değerlendirildi. Bulgular: Çalışmaya karaciğer biyopsisi yapılan toplam 34 olgu alındı. Fibrozis deresine göre 15 olgu hafif, 15 olgu orta ve 4 olgu ileri fibrozis grubundaydı. Gruplar arasında ortalama iskemi modifiye albümin ve iskemi modifiye albümin/albümin oranı düzeyleri anlamlı farklı saptandı (sırasıly; ; $p=0.031, p=0.044$ ). Gruplar arası değerlendirmede ileri fibrozis grubunda ortalama iskemi modifiye albümin ve iskemi modifiye albümin/albümin oranı; orta ve hafif fibrozis grubuna göre anlamlı farkl saptandı (sırasıly; $p=0.009$ ve $p=0.026, p=0.014$ ve $p=0.029$ ). Hafif ve orta fibrozis grupları arasında ortalama iskemi modifive albümin ve iskemi modifiye albümin/albümin oranı açısından anlamlı farklılık saptanmadı (sırasıyla, $p=0.545$ ve $p=0.673$ ). Sonuç: Karaciğer hastalıklarında ileri evre fibrozisi göstermede iskemi modifiye albümin ve iskemi modifiye albümin/albümin oranı etkin bir serum belirteci olarak kullanılabilir.

Anahtar kelimeler: Karaciğer, fibrozis, iskemi modifiye albümin

\section{Gíriş̧}

Kronik karaciğer hastalıklarında karaciğer biyopsisi hastalık tanısına ilave olarak hastalığın prognozu hakkında bilgi vermektedir. Hastalık prognozunu ön görmede, karaciğer inflamasyon ve fibrozisinin değerlendirilmesi son derece önemlidir. Karaciğer fibrozisini değerlendirmek için hali hazırda en iyi yöntem karaciğer dokusunun histopatolojik olarak değerlendirilmesidir (1). Histopatolojik değerlendirme en iyi yöntem olsa da işlemin girişimsel olması ve komplikasyonları nedeniyle kullanımı sınırlanmaktadır.

iletişim: Mustafa TAHTACI

Ankara Yıldırım Beyazıt Üniversitesi Tıp Fakültesi, İç Hastalııları Anabilim Dalı, Gastroenteroloji Bilim Dalı, Bilkent, Çankaya, Ankara, Türkiye Faks: +90 3122912627 • E-mail: drtahtaci@gmail.com
Background and Aims: Serum ischemia-modified albumin is a useful marker for ischemia and oxidative stress. The aim of this study was to evaluate the role of models based on serum ischemia-modified albumin and ischemia-modified albumin in predicting liver fibrosis. Materials and Methods: Patients who underwent liver biopsy for the diagnosis of chronic liver disease between 2013 and 2016 were included in this study. The same pathologist evaluated all the patients' biopsies. Patients were classified according to their fibrosis grades. The hemogram parameters, creatinine, aspartate aminotransferase, alanine aminotransferase, total bilirubin, direct bilirubin, albumin, ischemia-modified albumin, and ischemia-modified albumin/albumin ratio levels were evaluated in all cases. Results: A total of 34 patients who underwent liver biopsy were included in this study. According to the degree of fibrosis, 15 cases, 15 cases, and four cases were in the mild, moderate, and advanced fibrosis groups, respectively. Mean ischemia-modified albumin and ischemia-modified albumin/albumin ratio levels were significantly different between the groups ( $p=0.031, p=0.044$, respectively). The mean ischemia-modified albumin and ischemia-modified albumin/albumin ratio were significantly different in the advanced fibrosis group compared with the moderate and mild fibrosis groups $(p=0.009$ and $p=0.026$, $p=0.014$, and $p=0.029$, respectively). There was no significant difference between the mild and moderate fibrosis groups regarding the mean ischemia-modified albumin and ischemia-modified albumin/albumin ratio ( $p=0.545$ and $p=0.673$ ). Conclusion: Ischemia-modified albumin and ischemia-modified albumin/albumin ratio can be used as an effective serum marker for advanced liver fibrosis in liver diseases.

Keywords: Liver, fibrosis, ischemia-modified albumin

İskemi modifiye albümin (IMA), albüminin iskemiye bağlı olan yapısal değişikliğe bağlı oluşan formudur. İskemi ve oksidatif stres albüminin N-terminal bölgesinin kobalt, bakır ve nikel için bağlanma kapasitesini azaltarak iMA'yı oluşturur. IMA'nın özellikle vasküler iskemiyle direk ilişkili hastalıklarda belirgin olarak artış gösterdiği bildirilmektedir(2). Akut pankreatit ve apandisit gibi belirgin inflamasyonla giden durumlarda da IMA anlamlı artış göstermektedir $(3,4)$. Bununla beraber gebelik ve diyabet

Tahtacı M, Başaran M, Köseoğlu $H$, et al. Assessment of serum ischemia modified albumin in cases with liver fibrosis. The Turkish Journal of Academic Gastroenterology 2020;19:21-24. DOI: 10.17941/agd.723299

Geliş Tarihi: 01.03.2020 • Kabul Tarihi: 08.04.2020 
komplikasyonlarını öngörmede oldukça yararlı bir belirteç olarak kullanabileceğini belirten yayınlar da bulunmakta$\operatorname{dir}(5,6)$.

Kronik karaciğer hastalıklarında görülen fibrozis kronik karaciğer hastalığına hücresel düzeyde bir yanıtır. Hücresel düzeyde verilen bu yanıt sıklıkla oksidatif stres ile ilişkilidir (7). Biz bu çalışmada oksidatif stresin göstergelerinden biri olan IMA'nın karaciğer fibrosizinin derecesini belirlemede etkisinin değerlendirilmesini amaçladık.

\section{GEREÇ ve YÖNTEM}

Çalışmaya Yıldırım Beyazıt Üniversitesi Ankara Atatürk Eğitim ve Araştırma Hastanesi Gastroenteroloji Ünitesinde 2013-2016 tarihleri arasında kronik karaciğer hastalğı ön tanısıyla karaciğer biyopsisi yapılan hastalar dahil edildi. Çalışmada dışlama kriterleri; 18 yaş altında olma, bilinen koroner arter hastalı̆̆ı, periferik damar hastalı̆̆ı, serebrovasküler olay öyküsü, kalp yetmezliği öyküsü, gebelik ve histopatolojik inceleme için yeterli karaciğer dokusu alınamaması olarak belirlendi.

Çalışmaya dahil edilen tüm olguların karaciğer biyopsi materyalleri formalin ile fikse parafine gömülü bloklardan elde edilen Hematoksilen\&Eosin boyalı kesitler tekrar incelenmiştir. Olguların tamamının fibrosiz evrelemesi Masson Trikrom histokimyasal boyası kullanılarak yapımıştır. Olgular tanı kategorilerine göre uygun olan fibrozis evreleme sistemlerine göre tekrar skorlanmıştır. Buna göre "primer biliyer siroz/kolanjit" tanılı olgularda fibrozis evrelemesi için Batts/Ludwig Evreleme sistemi kullanılmış olup; portal fibrozis Evre 1, periportal alana ulaşmış fibrozis Evre 2, septal fibrozis Evre 3, siroz Evre 4 olarak tanımlanmıştır (8). Fibrozis grupları hafif (Batts/Ludwig 0-1), orta (Batts/Ludwig 2-3) ve ileri (Batts/Ludwig 4) olmak üzere üç gruba ayrıldı. Karaciğer biyopsisi viral hepatit, otoimmün hepatit ve diğer tanılı olgularda ise Ishak fibrozis evreleme sistemi kullanılmış olup, evreleme altı kategorili skorlama şeması üzerinden yapılmıştır. Ishak sistemine göre skorlanan vakalarda portal alanların bir kısmında izlenen fibrozis Evre 1, portal alanların çoğunda izlenen fibrozis Evre 2, nadir köprüleşme fibrozisi Evre 3, yaygın köprüleşme fibrosizi Evre 4, presirotik karaciğer Evre 5 ve siroz Evre 6 olarak değerlendirilmiştir (9). Fibrozis grupları hafif (Ishak 0-2) evre, orta (Ishak 3-4) evre ve ağır (Ishak 5-6) evre olmak üzere üç gruba ayrıldı.

IMA düzeyi, albümin kobalt bağlama testi ile ölçüldü. Kobalt-albümin bağlanması miyokardiyal iskeminin yeni belirteci olarak bir ön raporda sunulmuştur (10). Bu doğrultuda $200 \mu \mathrm{L}$ hasta serumu, $50 \mu \mathrm{L} 0.1 \%$ cobalt chloride ile karıştırııp 5 dakika süreyle inkübe edildi. Bu süreçte kobaltın albümine bağlanması sağlandı. İnkübasyondan sonra $50 \mu \mathrm{L}$ dithiothreitol (DTT) (Sigma, $1.5 \mathrm{mg} / \mathrm{ml} \mathrm{H2O}$ ) eklenerek karıştııılı ve DTT'nin albümine bağlanmamış kobalt ile renkli bir kompleks oluşturması sağlandı. Oluşan renkli kompleks $470 \mathrm{~nm}$ dalga boyunda spektrofotometrik olarak ölçüldü. Sonuçlar absorbance units (ABSU) olarak verildi.

Alanin aminotransferaz (ALT), aspartat aminotransferaz (AST), gamaglutamil transpeptidaz (GGT), total ve direk bilirübin düzeyleri ticari kitler kulanılarak (Roche Diagnostic, Mannheim, Almanya) Roche cobas-c501 otomatik analiz cihazı (Roche, Mannheim, Almanya) ile ölçüldü.

Istatistiksel analizler; Statistical Package for Social Sciences for Windows version 17.0 (SPSS, Chicago, IL) programıyla değerlendirildi. Tanımlayıcı veriler ortalama \pm tandart hata ve sayılarla ifade edildi. Kategorik verilerin karşılaştıılmasında Ki-kare testi kullanıldı. Verilerin dağıIım özelliği Shapiro-Wilk testi ile değerlendirildi. Normal dağılım özelliği gösteren verilerin karşılaştırımasına tek yönlü varyans analizi (ANOVA) testi ve post hoc Bonferroni testi kullanıldı. Normal dağılım göstermeyenler Kruskal Wallis testi ile karşılaştıııdı. $p<0.05$ değeri anlamlıık düzeyi olarak kabul edildi.

Etik Kurul onayı, Yıldırım Beyazıt Üniversitesi Tıp Fakültesi Klinik Araştırmalar Etik Kurulu'ndan alınmıştır (Etik kurul no: 12.07.2017 tarih 156 nolu karar).

\section{BULGULAR}

Çalışmaya toplam 34 olgu alındı. Fibrozis deresine göre 15 olgu hafif, 15 olgu orta ve 4 olgu ileri fibrozis grubundaydı. Olguların demografik, klinik ve laboratuvar özellikleri değerlendirildi. Olguların yaş ortalaması (yılıstandart hata) ve kadın olguların yüzdesi hafif, orta ve ileri grupta sırasıyla $49.86 \pm 2.83, \% 53.3 ; 50.20 \pm 3.02$, $\% 53.3 ; 59.00 \pm 3.69, \% 75$ olarak bulundu. Grupların yaş ortalaması ve cinsiyet oranı açısından anlamlı farklılık saptanmadı (sırasıyla, $p=0.323 ; p=0.374$ ). Karaciğer biyopsisi ön tanıları sıklık sırasına göre; hepatit B virüs (HBV) enfeksiyonu, primer biliyer siroz, otoimmün hepatit, hepatit $C$ enfeksiyonu ve diğer nedenlerden oluşturmaydı. Karaciğer biyopsi ön tanıları açısından gruplar arasında anlamlı farklılık saptanmadı ( $p=0.530)$. Gruplar arasında ortalama hemoglobin, lökosit, AST, ALT, total bilirubin ve direk bilirubin düzeyleri açısından da anlamlı fark saptanmadı (sırasıyla; $p=0.202, p=0.789, p=0.071, p=0.528$, $p=0.276, p=0.270$ ). Gruplar arasında ortalama trombosit sayısı, albumin, IMA ve iskemi modifiye albumin/albumin oranı (IMAO) düzeyleri arasında anlamlı fark saptandı (sırasiyla; $p=0.019, p=0.001, p=0.031, p=0.044$ ) (Tablo 1). Gruplar arası değerlendirmede ileri fibrozis grubunda ortalama albümin, IMA ve IMAO değerlerinde orta ve hafif 
Tablo 1. Fibrozis gruplarının demografik ve laboratuvar parametrelerinin karşılaştırılması

\begin{tabular}{|c|c|c|c|c|}
\hline & Hafif Fibrozis $(n=15)$ & Orta Fibrozis $(n=15)$ & İleri Fibrozis $(n=4)$ & $\mathbf{P}$ \\
\hline Kadın/erkek & $8 / 7$ & $8 / 7$ & $3 / 1$ & 0.374 \\
\hline Yaş (yıl) & $49.86 \pm 2.83$ & $50.20 \pm 3.02$ & $59.00 \pm 3.69$ & 0.323 \\
\hline Hemoglobin & $13.7 \pm 0.42$ & $13.9 \pm 0.55$ & $11.7 \pm 1.82$ & 0.202 \\
\hline Lökosit (x10³ $\mu \mathrm{L})$ & $6.93 \pm 0.65$ & $6.638 \pm 0.51$ & $6.05 \pm 1.13$ & 0.789 \\
\hline Trombosit ( $\left.\times 10^{3} \mu \mathrm{L}\right)$ & $228.33 \pm 22.2$ & $185.13 \pm 15.12$ & $112.25 \pm 17.19$ & ${ }^{*} 0.019$ \\
\hline AST (IU/L) & $112.23 \pm 67.9$ & $109.33 \pm 54.16$ & $145.50 \pm 61.17$ & 0.071 \\
\hline $\operatorname{ALT}(I U / L)$ & $196.60 \pm 116.6$ & $104.40 \pm 29.77$ & $130 \pm 64.42$ & 0.528 \\
\hline Total bilirübin (IU/L) & $1.28 \pm 0.57$ & $0.77 \pm 0.20$ & $5.46 \pm 4.64$ & 0.276 \\
\hline Direk bilirübin (IU/L) & $0.92 \pm 0.53$ & $0.48 \pm 0.21$ & $3.54 \pm 3.16$ & 0.270 \\
\hline Albümin $(\mu \mathrm{g} / \mathrm{g})$ & $4.47 \pm 0.09$ & $4.39 \pm 0.10$ & $3.46 \pm 0.33$ & *0.001 \\
\hline IMA & $0,71 \pm 0,03$ & $0,70 \pm 0,05$ & $1,67 \pm 0,82$ & ${ }^{\star} 0,031$ \\
\hline IMAO & $0,16 \pm 0,01$ & $0,16 \pm 0,01$ & $0,54 \pm 0,30$ & ${ }^{*} 0,044$ \\
\hline
\end{tabular}

* Istatiksel olarak anlamlı

AST: Aspartat transaminotransferase; ALT: Alanin transaminotransferase; IMA: İskemi modifiye albümin; IMAO: İskemi modifiye albüminin albümine oranı Parametreler $n$ veya ortalama \pm standart hata olarak verilmiştir.

fibrozis grubuna göre anlamlı farklılık saptandı (sırasıyla; $p=0.001$ ve $p=0.001, p=0.009$ ve $p=0.026, p=0.014$ ve $p=0.029)$. Hafif ve orta fibrozis grupları arasında ortalama albümin, IMA ve IMAO açısından anlamlı farklılık saptanmadı (sırasıyla; $p=1.000, p=0.545, p=0.673$ ). Ortalama trombosit düzeyi ileri fibrozis grubunda hafif fibrozis grubunda göre anlamlı düşük saptanırken, orta fibrozis grubuyla anlamlı farklılık saptanmadı (sırasıyla; $p=0.020$, $p=0.181$ ).

\section{TARTIŞMA}

Karaciğer fibrozisinin değerlendirilmesinde laboratuvar ve görüntüleme yöntemleri gibi birçok girişimsel olmayan yöntemler değerlendirilmektedir. Buna karşın inflamasyon ve fibrozisi göstermede etkili uygun bir metot tanımlanmamıştır. Çalışmalar kronik karaciğer hastalıklarında IMA ve IMAO'nun fibrozisin derecesini belirlemede destekleyici bir belirteç olarak kullanılabileceğini göstermektedir.

Karaciğer hastalıklarında fibrozisin değerlendirilmesinde biyopsi en etkili yöntemdir. Buna karşın işleme bağlı ağrı, kanama gibi komplikasyonlar ve yetersiz örnekleme yapılabilmesi işlemi sınırlandıran faktörlerdir. Karaciğer fibrozisinin değerlendirilmesinde birçok girişimsel olmayan laboratuvar testleri, skorlamalar ve görüntüleme yöntemleri kullanılmaktadır (11). Skorlamada kullanılan rutin testlerde sıklıkla trombosit, albümin ve AST parametreleri kullanılmaktadır. Çalışmamızda albümin ileri fibroz grubunda, hafif ve orta fibrozis grubuna göre anlamlı düşük saptandı. Fakat hafif ve orta fibrozis grubu arasında albümin düzeyi açısından anlamlı farklılık saptanmadı. Trombosit düzeyi açısından ileri fibroz grubunda hafif fibrozis grubuna göre anlamlı düşüklüğü saptanırken, orta fibrozis grubu ile diğer gruplar arasında anlamlı farklılık saptanmadı. Skorlamalar ve rutin parametreler ileri fibroz ve hafif veya fibrozis yokluğunu gösterebilse de ara evreleri belirlemede etkili olamamaktadır (12).

IMA iskemik hasar ve oksidatif hasarı gösteren, yapısal değişiklik geçiren albümin formudur. Karaciğer hastalğında iskemi modifiye albüminin değerlendirildiği birkaç çalışma bulunmaktadır. Dekompanse sirozlu hastalarda albüminin fonksiyonel kapasitesindeki değişikliklerin artmış mortalite ile ilişkili olduğu bildirilmektedir (13). IMA; kronik hepatitli veya sirozlu hastalarda, sağlıklı gönüllülerle karşılaştııılığında anlamlı yüksek bulunmuştur (14). Akut komplikasyon nedeniyle hospitalize edilen 127 pediatrik sirozlu olgunun değerlendirildiği bir çalışmada, iMA'nın hastalık şiddeti skorları ile korelasyon göstermediği, ancak özellikle bakteriyel enfeksiyonlarda C-reaktif protein'e (CRP) benzer bir ayırt edici performans gösterebileceği bildirilmiştir (15).

IMAO, hastalık şiddeti ile ilişkilidir ve akut ya da kronik karaciğer yetmezliğinde prognostik kullanıma sahip olabilir (13). IMA'nın albümine oranının karaciğer fonksiyonu ve oksidatif stresi yansıtan 3 günlük albümin infüzyonundan etkilenmeyen IMA'ya göre daha objektif bir karaciğer fonksiyon testi olduğu bildirilmektedir (14). Kronik karaciğer hastalığı olan hastalarda iMAO'nun, Model for 
End Stage Liver Disease (MELD) ile pozitif korelasyon gösterdiği, hastalık şiddeti ve prognozunu değerlendirmek için bir biyobelirteç görevi görebileceği belirtilmektedir (16). Kronik hepatit B'ye bağı kronik karaciğer hastalğında IMA ve IMAO'nun, karaciğer fibrozisinin derecesi ile anlamlı ilişkili olduğu bildirilmektedir (17). Çalışmamızda IMA ve IMAO düzeyleri ileri evrede hafif ve orta evre fibrozis gruplarına göre anlamlı yüksek saptanmış, ara fibrozis evrelerini göstermede etkin bulunmamıştır.

Karaciğer hastalıklarında, karaciğer hastalık tipine göre fibrozisin patogenezinde genetik ve non genetik faktörler rol oynamaktadır. Karaciğer fibrozisi çoğu karaciğer hastalığında ektrasellüler matriks proteinlerinin miktarı ve içeriğindeki değişiklikler ile oluşmaktadır (18). Bu değişikliklere neden olan faktörlerden biri vazokonstrüktör özelliklere sahip sitokinlerdir. Bu sitokinler yoluyla yüksek oksidan seviyeleri oluşmakta ve redoksa duyarlı hücre içi

\section{KAYNAKLAR}

1. Grant A, Neuberger J. Guidelines on the use of liver biopsy in clinical practice. British Society of Gastroenterology. Gut 1999;45(Suppl 4):IV1-IV11.

2. Gaze DC. Ischemia modified albumin: a novel biomarker for the detection of cardiac ischemia. Drug Metab Pharmacokinet 2009;24:333-41.

3. Topaloglu N, Kucuk A, Tekin M, et al. Serum ischemia-modified albumin levels in experimental model of acute pancreatitis. J Coll Physicians Surg Pak. 2015;25:395-8.

4. Reddy VS, Perugu B, Garg MK. Ischemia-modified albumin must be evaluated as an oxidative stress marker together with albumin and bilirubin in individuals with acute appendicitis. Clinics (Sao Paulo) 2015;70:531-2.

5. Seshadri Reddy V, Munikumar M, Duggina P, Varma N. A diagnostic test accuracy meta-analysis of maternal serum ischemia-modified albumin for detection of preeclampsia. J Matern Fetal Neonatal Med. 2018;24:1-9.

6. Ghosh K, Muddeshwar MG, Ghosh K. Ischemia modified albumin test to detect early diabetic complications. Am J Med Sci 2017;354:467-70.

7. Parola M, Robino G. Oxidative stress-related molecules and liver fibrosis. J Hepatol 2001;35:297-306.

8. Batts KP, Ludwig J. Chronic hepatitis. An update on terminology and reporting. Am J Surg Pathol 1995;19:1409-17.

9. Ishak K, Baptista A, Bianchi L, et al. Histological grading and staging of chronic hepatitis. J Hepatol 1995;22:696-9. yollar uyarılmaktadır (12). IMA ve IMAO'nun fibroziste belirgin yükselmesi bu yollar aracilığı ile oluşabilir.

Çalışmamızın bazı sınırlııkları bulunmaktadır. Karaciğer fibrozis grupları arasındaki hasta sayıları yeterli değildir. Kronik karaciğer hastalığı tanısı, gruplar açısında anlamlı farklı olmasa da homojen değildir. Olgu sayılarının yeterli ve belirli etiyolojinin değerlendirildiği çalışmalara intiyaç bulunmaktadır. Çalışmanın bir diğer sınırlıı̆ı iMA'nın serum seviyelerinde değişiklik olup olmadığı değerlendirmek için aralıkı değerlendirme yapılmamıştır.

Sonuç olarak kronik karaciğer hastalıklarında fibrozis hem prognoz öngörüsü sağlamakta hem de tedavi planında etkili olabilmektedir. IMA ve IMAO ileri evre fibrozisi göstermede etkin bir serum belirteci olarak kullanılabilir.

\section{"Tüm yazarlar herhangi bir çıkar çatışması olmadığını kabul ederler."}

10. Bar-Or D, Lau E, Winkler JV. A novel assay for cobalt-albumin binding and its potential as a marker for myocardial ischemia-a preliminary report. J Emerg Med 2000;19:311-5.

11. Chin JL, Pavlides M, Moolla A, Ryan JD. Non-invasive markers of liver fibrosis: adjuncts or alternatives to liver biopsy? Front Pharmacol 2016;7:159.

12. Bataller R, Brenner DA. Liver fibrosis. J Clin Invest 2005;115:20918.

13. Jalan R, Schnurr K, Mookerjee RP, et al. Alterations in the functional capacity of albumin in patients with decompensated cirrhosis is associated with increased mortality. Hepatology 2009;50:555-64.

14. Chen CY, Tsai WL, Lin PJ, Shiesh SC. The value of serum ischemia-modified albumin for assessing liver function in patients with chronic liver disease. Clin Chem Lab Med 2011;49:1817-21.

15. Giannone FA, Domenicali M, Baldassarre M, et al. Ischaemia-modified albumin: a marker of bacterial infection in hospitalized patients with cirrhosis. Liver Int 2015;35:2425-32.

16. Kumar PA, Subramanian K. The role of ischemia modified albumin as a biomarker in patients with chronic liver disease. J Clin Diagn Res 2016;10:BC09-12

17. Yavuz F, Biyik M, Asil M, et al. Serum ischemic modified albumin (IMA) concentration and IMA/albumin ratio in patients with hepatitis B-related chronic liver diseases. Turk J Med Sci 2017;47:947-53.

18. Benyon RC, Iredale JP. Is liver fibrosis reversible? Gut 2000;46:4436. 